\title{
Encefalite autolimitada na COVID-19: relato de um caso
}

\author{
Self-limited encephalitis in COVID-19: a case report
}

\author{
Marcos Manoel Honorato ${ }^{1,2^{*}} \bullet$, Adriane Cristina Vieira dos $\operatorname{Santos}^{1 \bullet}$, Felipe Luan Lima da Silva ${ }^{1}$, $^{\circ}$ \\ Renata Carvalho Cremaschi ${ }^{2} \bullet$, Fernando Morgadinho Coelho ${ }^{2} \bullet$
}

${ }^{1}$ Universidade do Estado do Pará, Santarém, Pará, Brasil. ${ }^{2}$ Departamento de Neurologia e Neurocirurgia, Universidade Federal de São Paulo, São Paulo, Brasil. *Autor para correspondência. E-mail: marcosmhonorato@hotmail.com

\begin{abstract}
Resumo: Introdução: COVID-19 é uma infecção sistêmica pelo novo coronavírus (SARS-COV2), que surgiu na China em 2019 e tem assolado o mundo. Sua taxa de contágio é elevada e já causou milhões de mortes em todos os continentes. Embora assintomática na maioria dos pacientes, muitos casos geralmente provocam síndrome respiratória aguda grave. Sintomas neurológicos, principalmente cefaléia, anosmia e confusão mental, são proeminentes, possivelmente devido ao envolvimento direto de estruturas cerebrais ou do sistema nervoso periférico. Casos de encefalite grave tem sido relatado em vários países. Perda de memória parece ser uma sequela frequente. Relato de caso: Nós descrevemos o caso de uma mulher jovem que apresentou crises epilépticas devido à infecção pelo coronavírus, com alterações no líquor e anormalidades transitórias na neuroimagem, evoluindo com melhora espontânea. Discussão: Nossos achados sugerem a existência de casos de encefalite pós-covid de natureza autoimune com evolução benigna, uma entidade potencialmente subdiagnosticada diante das manifestações mais graves da pandemia, e talvez responsável por sequelas como perda de memória e anosmia.
\end{abstract}

Palavras-chave: COVID-19, crises epilépticas, encefalite autoimune, pandemia.

\begin{abstract}
Introduction: COVID-19 is a systemic infection with the new coronavirus (SARS-COV2), which appeared in China in 2019 and has been plaguing the world. Its contagion rate is high and has already caused millions of deaths on all continents. Although it is asymptomatic in most patients, many cases usually lead to severe acute respiratory syndrome. Neurological symptoms, especially headache, anosmia and mental confusion, are prominent, possibly due to direct involvement of brain structures or the peripheral nervous system. Cases of critical encephalitis have been reported in several countries. Memory loss seems to be a commom sequel. Case report: We describe the case of a young woman who presented epileptic seizures due to coronavirus infection, with changes in the cerebrospinal fluid and transient abnormalities in neuroimaging, evolving with spontaneous improvement. Discussion: Our findings suggest the existence of cases of post-covid encephalitis from autoimmune nature and benign evolution, a potentially underdiagnosed entity in the face of the most serious manifestations of the pandemic, and perhaps responsible for sequelae such as memory loss and anosmia.
\end{abstract}

Keywords: COVID-19, epileptic seizures, autoimmune encephalitis, pandemic.

\section{Introduction}

The new coronavirus pandemic spread rapidly across all continents in 2020. Despite being an eminently respiratory disease, multiple clinical forms and neurological manifestations have been reported. Anosmia, hypogeusia and headache are very common, but Guillain-Barré syndrome and encephalitis are particularly challenging due to the diversity of clinical findings, often dissociated from complementary exams (CarodArtal, 2020). Sohal e Mossammat (2020) described an interesting case of related-covid encephalitis in a critical patient with multiple comorbidities (diabetes, renal and respiratory failure) and bad outcome (Sohal \& Mossammat, 2020) Other authors have already reported similar cases with variable response to steroid or plasmapheresis. All patients were severe and complementary exams and the outcome varied a lot (Pilotto et al., 2020; Romero-Sánchez et al., 2020). SARS-COV2 infection is multiplying around the world, including South America and remote areas in Brazil. We report an encephalitis with spontaneous remission in a patient with COVID-19, who lives in Amazonia, highlighting possible underestimation of this neurological scenario, perhaps responsible for mild symptoms and sequelae. This research was authorized and followed international ethical standards. 


\section{Case report}

A 33-year-old woman, previously healthy, reported fever, cough, asthenia and anosmia for 15 days, without dyspnea. She was hospitalized after continuous bilateral pulsatile frontal headache, mood change and two generalized seizures in 24 horas. Her medical history evidenced childhood febrile seizures. RT-PCR test for COVID-19 was positive. She was in regular general condition and eupneic. The neurological examination and electroencephalogram were normal. Lumbar puncture showed cerebrospinal fluid without pleocytosis, with normal levels of glucose and mild high protein. RT-PCR test for coronavirus and oligoclonal bands in CSF were negative. At admission, brain magnetic resonance imaging (MRI) demonstrated a slight hyperintensity in left frontal and temporal lobes, predominantly in the precentral gyrus (FLAIR and T2 sequences), without enhancement after gadolinium. (Figure 1). Ten days later, facing persistent headaches and mainly to look over vascular complication, a new MRI and cerebral angioresonance revelead no abnormalities. She had a good outcome after treatment with sodium divalproate. After 3 months the patient complained of subjective memory loss.
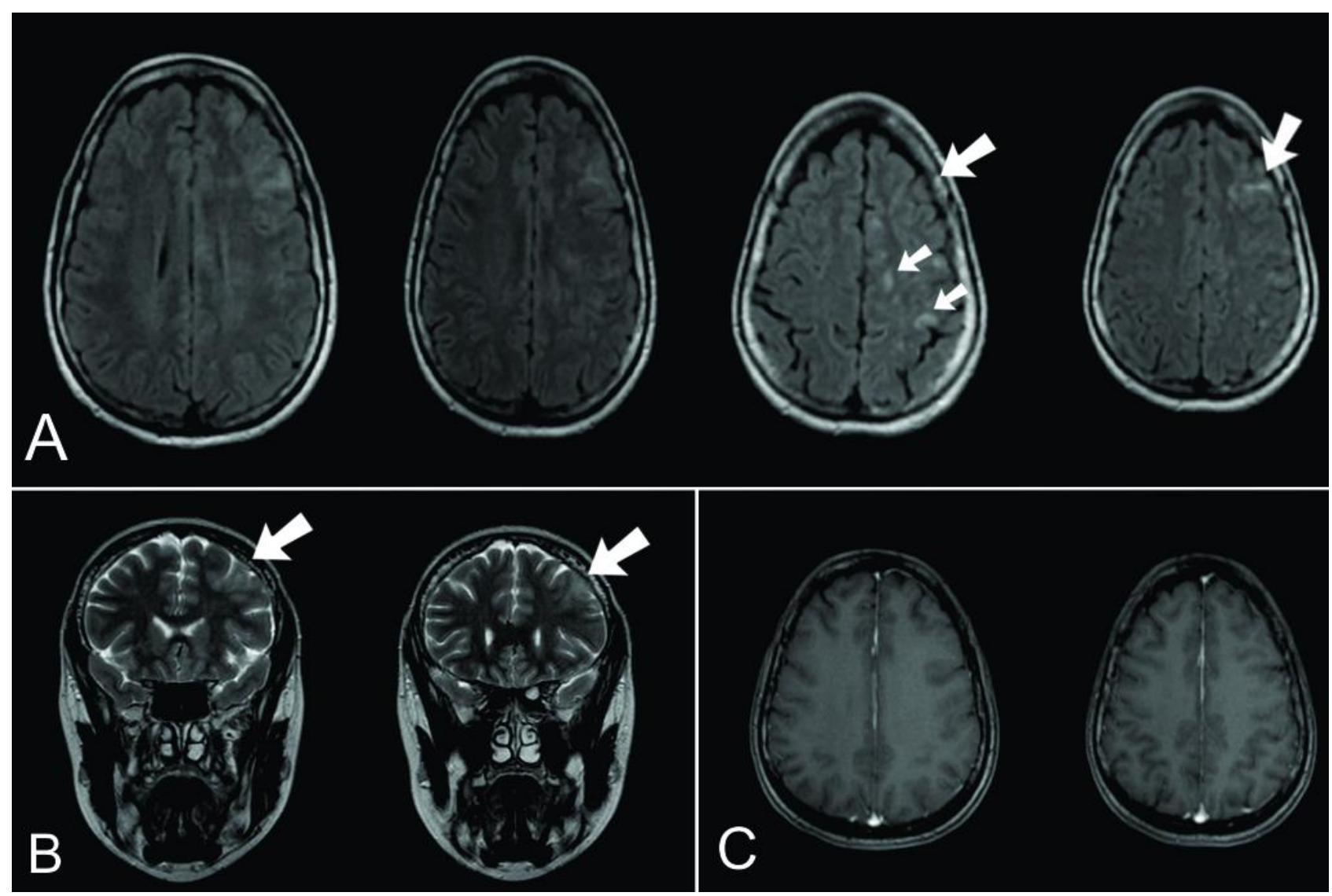

Figure 1. MRI detected hiperintensity in precentral gyrus and temporal lobe in FLAIR axial sequence (A), T2 coronal sequence (B) without enhancement after gadolinium injection in $\mathrm{T} 1$ axial sequence (C).

\section{Discussion}

A variety of neurological manifestations of COVID-19 have been reported (Mao et al., 2020). Anosmia and headache are frequent, seizures are rare, and up to thirty-four percent of patients reported memory loss within months of infection (Garrigues et al., 2020) Pathophysiological mechanisms are still uncertain (Wu et al., 2020). Fleeting cerebral lesions we described, with poor clinical findings correspondence, were found in sites commonly associated with herpes virus type 1 (HSV-1) encephalitis. Thought the nasopharyngeal mucosa and neuronal pathway, HSV-1 reaches cortical and subcortical bilateral temporal and frontal lobes, and the insula. In our patient, central nervous system damage caused by SARS-COV2, anosmia and imaging findings indicate that transport by the olfactory nerve may coexist in association with immune or direct injury. The encephalitis occurrence among the moderate prevalence of neurological manifestations in COVID-19 corroborates to our theory of possible unrecognized cases of autoimmune encephalitis (Romero-Sánchez et al., 2020). MRI abnormalities have been found in many patients with this infection. They mainly affect the 
gray matter of the olfactory cortices, hippocampi, insulas, left rolandic operculum, left Heschl's gyrus. The presence of these lesions was statistically correlated with memory loss and suggested possible disruption to micro-structural and functional brain integrity in the recovery stages of COVID-19. Hypersinal in the right cingulate gyrus and left hippocampus correlated with smell disfunction. This may account for long-term consequences and mild sequelae in SARS-COV2 infection (Lu et al., 2020). The predominance of multisystem and nonspecific neurological symptoms challenges the doctors to select which priorities investigate. A patient with non-severe neurological symptoms, and no focal signs, makes the search for self-limiting infection even greater difficulty (Serrano-Serrano et al., 2020). The transitory unspecific MRI findings drive for a spectrum of post-SARS-COV2 immunomodulated encephalitis (Dalmau, \& Graus, 2018; Le Guennecet al, 2020). This contributes to supporting evidence of the role of the immune system in the pathophysiology of the disease and its sequelae. Indeed, we can expect limited settings in the outcome of encephalitis, during the pandemic timeline, with challenges in investigation and care.

\section{References}

Carod-Artal, F. J. 2020. Complicaciones neurológicas por coronavirus y COVID-19. Rev Neurol, 70(9), 311-322.

Dalmau, J., \& Graus, F. 2018. Antibody-mediated encephalitis. New England Journal of Medicine, 378(9), 840851.

Garrigues, E., Janvier, P., Kherabi, Y., Le Bot, A., Hamon, A., Gouze, H., ... \& Nguyen, Y.(2020. Post-discharge persistent symptoms and health-related quality of life after hospitalization for COVID-19. Journal of Infection, 81(6), e4-e6.

Le Guennec, L., Devianne, J., Jalin, L., Cao, A., Galanaud, D., Navarro, V., ... \& Demeret, S. 2020. Orbitofrontal involvement in a neuroCOVID-19 patient. Epilepsia, 61(8), e90-e94.

Lu, Y., Li, X., Geng, D., Mei, N., Wu, P. Y., Huang, C. C., ... \& Yin, B. 2020. Cerebral micro-structural changes in COVID-19 patients-an MRI-based 3-month follow-up study. EClinicalMedicine, 25, 100484.

Mao, L., Jin, H., Wang, M., Hu, Y., Chen, S., He, Q., ... \& Hu, B. 2020. Neurologic manifestations of hospitalized patients with coronavirus disease 2019 in Wuhan, China. JAMA neurology, 77(6), 683-690.

Pilotto, A., Odolini, S., Masciocchi, S., Comelli, A., Volonghi, I., Gazzina, S., ... \& Padovani, A. 2020. Steroidresponsive encephalitis in coronavirus disease 2019. Annals of neurology, 88(2), 423-427.

Romero-Sánchez, C. M., Díaz-Maroto, I., Fernández-Díaz, E., Sánchez-Larsen, Á., Layos-Romero, A., GarcíaGarcía, J., ... \& Segura, T. 2020. Neurologic manifestations in hospitalized patients with COVID-19: the ALBACOVID registry. Neurology, 95(8), e1060-e1070.

Serrano-Serrano, B., López-Hernández, N., Dahl-Cruz, F., Elvira-Soler, E., \& Díaz-Marín, C. 2020. Encefalitis multifocal como manifestación neurológica de la infección por COVID-19. Rev Neurol, 351-352.

Sohal, S., \& Mansur, M. 2020. COVID-19 presenting with seizures. IDCases, 20, e00782.

Wu, Y., Xu, X., Chen, Z., Duan, J., Hashimoto, K., Yang, L., ... \& Yang, C. 2020. Nervous system involvement after infection with COVID-19 and other coronaviruses. Brain, behavior, and immunity, 87, 18-22.

\section{Minicurrículo}

Marcos Manoel Honorato. Médico-neurologista; Docente do Curso de Medicina da Universidade do Estado do Pará (UEPA) Campus Santarém; Aluno de Doutorado do Programa de Pós-graduação em Neurologia e Neurociências da Universidade Federal de São Paulo (UNIFESP).

Adriane Cristina Vieira dos Santos. Graduanda em Medicina pela Universidade do Estado do Pará (UEPA) Campus Santarém.

Felipe Luan Lima da Silva. Graduando em Medicina pela Universidade do Estado do Pará (UEPA) Campus Santarém.

Renata Maria de Carvalho Cremaschi. Médica-neurologista; Doutora em Ciências pelo Departamento de Psicobiologia da Universidade Federal de São Paulo (UNIFESP). 
Fernando Morgadinho Santos Coelho. Médico-neurologista; Livre-docente do Departamento de Neurologia e Neurocirurgia da Universidade Federal de São Paulo (UNIFESP).

Como citar: Honorato, M.M., Santos, A.C.V., Silva, F.L.L., Cremaschi, R.M.C., \& Coelho, F.M.S. 2021. Encefalite autolimitada na COVID-19: relato de um caso. Pubsaúde, 7, a225. DOI: https://dx.doi.org/10.31533/pubsaude7.a225

Recebido: 11 jul. 2021.

Revisado e aceito: 21 jul. 2021.

Conflito de interesse: os autores declaram, em relação aos produtos e companhias descritos nesse artigo, não ter interesses associativos, comerciais, de propriedade ou financeiros que representem conflito de interesse.

Licenciamento: Este artigo é publicado na modalidade Acesso Aberto sob a licença Creative Commons Atribuição 4.0 (CC-BY 4.0). 